\title{
悪性脳腫瘍に対する熱感受性リポソームと 脳組織内加温による化学温熱療法
}

\author{
柿沼健一・田中隆一 ・高橋英明 - 須田 剛*1)，加藤 仁*2)
}

Chemo-thermotherapy for malignant brain tumor with the combination of thermosensitive liposome and interstitial hyperthermia

Malignant glioma responds poorly to chemotherapy presumably mainly because the antitumor drugs can not be delivered in effective concentrations to the tumor site without causing complications, and because the existence of the blood-brain barrier (BBB) restricts the distribution of many antitumor drugs to malignant gliomas. We used thermosensitive liposomes containing CDDP (cisdiamminedichloroplatinum) with localized heating, and the possibilities of this drug delivery system to the brain tumor were discussed. First, this unique and attractive strategy showed remarkable effects against the RSV-induced subcutaneous tumor which was relatively insensitive to various antitumor agents.

The authors then investigated the antitumor effect on rat malignant brain tumor. Ten days after tumor inoculation, six groups were formed: control, free CDDP, hyperthermia, free CDDP + hyperthermia, CDDP-liposome, and CDDP-liposome+ hyperthermia. Liposomes containing CDDP (CDDPliposome) or free CDDP were injected via the tail vein. The brain tumor heating was given using a radiofrequency antenna which was designed at our institute. As a result, the rats treated by CDDPliposome+hyperthermia had the longest survival time, and the tumor CDDP level of this group was the highest when compared to other groups.

These findings suggest that the combination of thermosensitive liposome and localized hyperthermia could (1) bring a direct thermal killing of the tumor cells, plus (2) increase a permeability of the

*1) Department of Neurosurgery, Brain Research Insti. tute, Niigata University 新潟大学䑈研究所脑神経外科

-21 Division of Pharmacy, Niigata University Medical Hospital 新晹大学医学部附属病院蔈剂部

Offprint requests to : Kenichi Kakinuma, M.D., Depart. ment of Neurosurgery, Brain Research Institute, Niigata University, 1-757 Asahimachi-dori, Niigata 951
$\mathrm{BBB}$ to transport of CDDP, plus (3) target CDDPliposomes to the tumor site and produce an effective release of liposomal CDDP with greater activ. ity than when free CDDP was injected.

Kenichi Kakinuma $\cdot$ Ryuichi Tanaka $\cdot$ Hideaki Takahashi $\cdot$ Tsuyoshi Suda*11, Masashi Kato*2)

key words : hyperthermia, thermosensitive liposome, targeting chemotherapy, malignant brain tumor, CDDP

抗癌剤の多くは悪性腫瘍に対して強い殺細胞効 果を有する反面, 副作用も多く, 治療係数は概し て小さい。ささらに脳腫瘍においては，血液脳関門 の存在が腫瘍内への抗癌剤の到達を妨げ,一層治 療係数が小さくなることが知られている、なかで も悪性グリオーマはきわめて予後のわるいものと して知られ、さまざまな化学療法が試みられてき たが，今日までその予後はほとんど改善されてい ないといっても過言ではない.

筆者らは, これまで悪性脳腫㾤の組織内温熱療 法に用いる radiofrequency (RF) 加温装置の試作 開発とともに温熱療法の基毞的研究を行ってきて おり, すでに RF 加温装置を用いて臨床応用を行 い, すぐれた成績を報告している ${ }^{1 \sim 6)}$.さらに筆者 らは, この局所温熱療法に，抗癌㓮を封入した熱 感受性リポソームを組み合わせることによって, 悪性脳腫瘍に対する新しい化学温熱療法の可能性 について検討した。

\section{材料と方法}

\section{（1）熱感受性リポソームの調整}

熱感受性りポソームは reverse-phase evaporation 法によって作製した. dipalmitoylphosphatidylcholine $と$ distearoylphosphatidylcholine を 


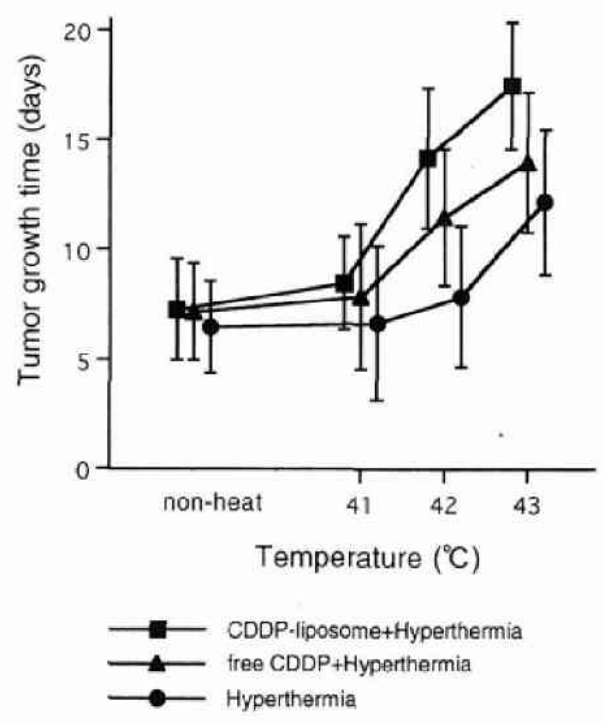

図 1 Temperature-response curves The combination of CDDP-liposome and hyperthermia at $42^{\circ} \mathrm{C}$ and $43^{\circ} \mathrm{C}$ showed a significant tumor growth delay compared with free CDDP and hyperthermia alone.

9:1のモル比で isopropylether と chloroform の混合溶媒 (1：1)に溶解したあと, CDDP (cisdiamminedichloroplatinum) を加えて擋汼し，10 分間の sonication を行った. その後, vacuum evaporator にて溶禁を除去し, 透析で free の CDDP を除き，約 $80 \%$ の CDDP が $41^{\circ} \mathrm{C}$ 以上で放 出されように設定された CDDP 封入熱感受性り ポソーム (CDDP-liposome) を作製した7).

（2）皮下腫瘍に対する抗腫瘍効果の検討

筆者らは，まずはじめにこの CDDP-liposome を用い, マウスの皮下腫湟グリオーマモデルで局 所温熱療法との併用効果について検討した. $10^{5}$ 個 の Rous sarcoma virus (RSV)誘発グリオーマ細 胞を $\mathrm{C} 3 \mathrm{H} / \mathrm{He}$ マウスの大腿皮下に移植し，12 日 から 14 日後, 腫瘍の大きさが一定になった時点 で Group A (free CDDP 単独投与), Group B (hyperthermia), Group C (free CDDP と hyperthermia の併用), Group D (CDDP-liposome 単 独投与), Group E (CDDP-liposome と hyperthermia の併用) の 5 治療群 (各群 $\mathrm{n}=20 \sim 30$ 匹) に わけ実験を行った．抗腫瘍効果の判定は腫瘍体積 が 4 倍になるまでの日数の比較とし, 加温は恒温
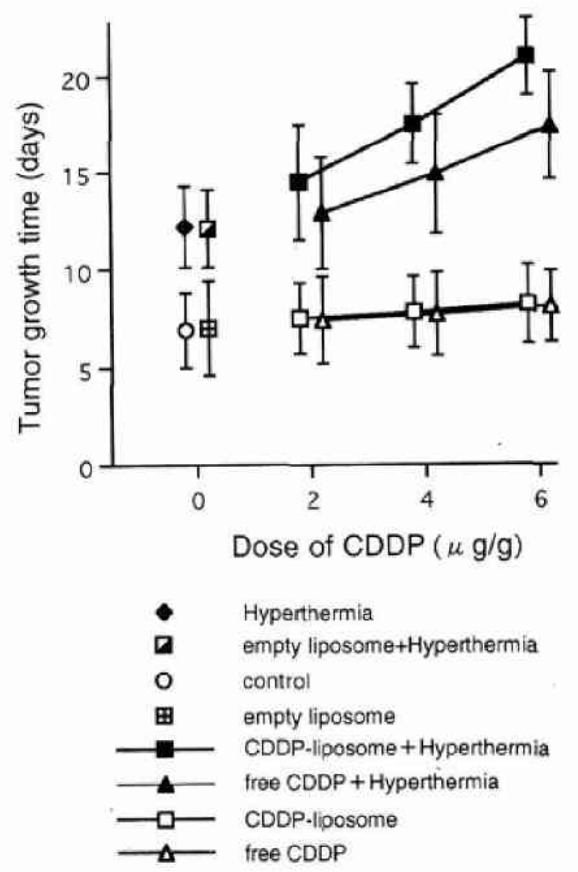

図 2 Dose-response curves The combination of CDDP-liposome and hyperthermia was most effective per amount of CDDP in delaying tumor growth.

槽を用いた。

まず $41,42,43^{\circ} \mathrm{C}$ 各温度で 60 分間腫陽を温浴 させ，温度の違いによる抗腫浧効果を検討した。 薬剂はすべて加温直前に尾静脈から注入したが, それぞれは CDDP に換算して $4 \mu \mathrm{g} / \mathrm{g}$ で行われ た.

次いで, 加温を $43^{\circ} \mathrm{C} て ゙ 60$ 分間行い, $2,4,6 \mu \mathrm{g} /$ $\mathrm{g}$ の 3 通りの投与量の違いによる抗腫瘍効果も同 時に検討した。

\section{（3） CDDP-liposome の体内薬理動態}

腫湯組織内および血液中の, CDDP 濃度の推移 について検討した。薬剤の投与量はいずれも CDDP に換算して $4 \mu \mathrm{g} / \mathrm{g}$, 加温はいずれも $43^{\circ} \mathrm{C}$ で 60 分間行われた. 薬凨注入の 20 分後に加温を 開始し, 加温開始時, $30,60,120$ 分後に心荿穿刺 で採血し、腫瘍を摘出したのち, CDDP 濃度を $\mathrm{Pt}$ 濃度として atomic absorption spectrophotometer で測定した. 


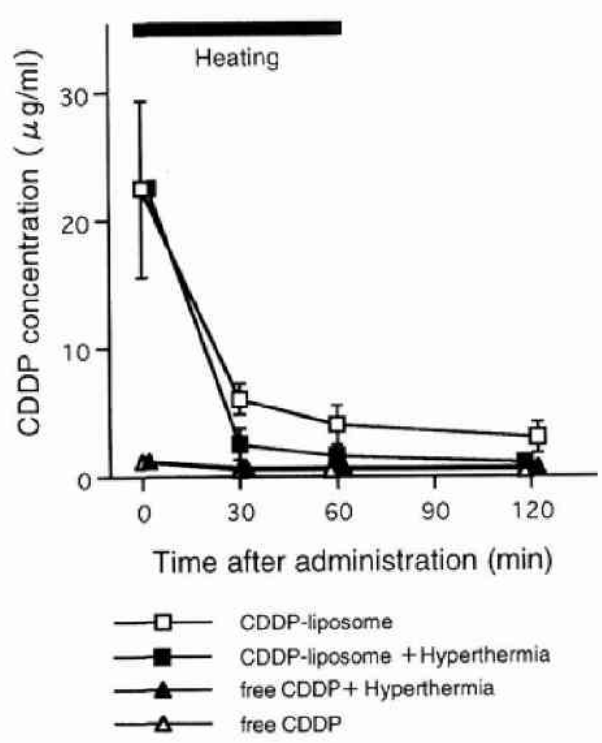

図 3 Time course of CDDP levels in blood When CDDP was encapsulated in liposomes, the slower blood clearance of CDDP was seen. Then blood CDDP levels decreased rapidly corresponding to the start of heating.

\section{（4）脳腫瘍に対する抗腫激効果の検討}

次いで, ラットの脳腫啺グリオーマモデルで本 法の抗腫瘍効果について検討を行った. Fisher ラット脳内に RSV 誘発グリオーマ細胞 $10^{5}$ 個を 移植し, 10 日目に Group 1 (control), Group 2 (free CDDP 単独投与), Group 3 (hyperthermia), Group 4 (free CDDP と hyperthermia $の$ 併用), Group 5 (CDDP-liposome 単独投与), Group 6 (CDDP-liposome と hyperthermia の併 用)の 6 治療群 (各群 $\mathrm{n}=10$ 匹) にわけ, 生存期間 をみた，加温方法は，筆者らの施設で試作開発し てきた組織内温熱療法を用いた，すなわち，径 1.0 $\mathrm{mm}$ の RF アンテナを腫癔中央に刺入し, 腫瘄内 温度は腫陽内にアンテナと平行に刺入した径 0.8 $\mathrm{mm}$ 多点式温度計で，複数の個所で同時に，かつ real time にモニトターしながら RF generator を操作し, 腫韵内温度が $41^{\circ} \mathrm{C}$ 以上になるようにコ ントロールした。まず 15 分間加温したのち, CDDP に換算して $6 \mu \mathrm{g} / \mathrm{g}$ の free CDDP, あるい は CDDP-liposome を尾静脈から注入し, さらに

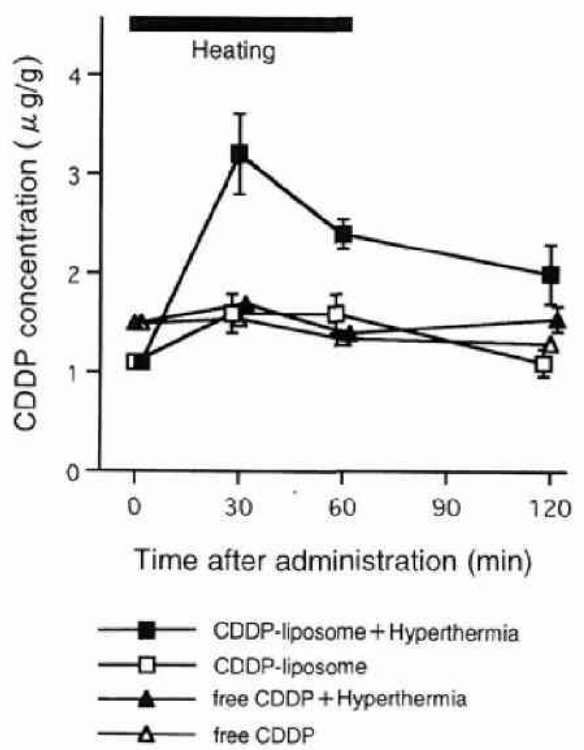

图 4 Time course of CDDP levels in tumor

The tumor uptake of liposomal CDDP was markedly increased by heating.

15 分間の加温を行った.

また移植 15 日目に, Group 2, Group 4, Group 5, Group 6 で同様の治療を行った直後に, 脳腫瘍 を摘出し, 腫瘍内 CDDP 濃度を測定した(各群 $\mathrm{n}=10$ 匹).

\section{結 果}

（1）皮下腫湯に対する抗腫湯効果

(1) 加温温度別の抗腫瘍効果 (図 1)

Group B, Group C, Group D とも加温温度の

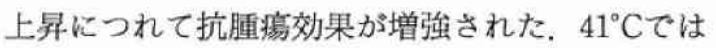
Group C, Group D の 2 群は, Group B に対しご く軽度の温熱增強効果がみられたのみで, 両者に 差はなかったが, $42,43^{\circ} \mathrm{C} の$ 加温を併用すると, Group D ては Group B, Group C に対して有意 な抗腫瘍効果がみられた $(\mathrm{P}<0.05$ : Student's ttest).

(2) 薬威投与量別の抗腫瘍効果 (図 2)

加温を併用しなかった群で比較すると, Group D は Group A と同等の効果がみられたに過ぎな かった. 一方, 加温を併用した Group C, Group 
表 1 The median survival time among the groups

\begin{tabular}{lccl}
\hline \multicolumn{1}{c}{ Group } & Cases & Mean survival(days) & \multicolumn{1}{c}{$P$ value } \\
\hline Group 1 (control) & 10 & $19.5 \pm 2.5$ & \\
Group 2(free CDDP) & 10 & $20.1 \pm 3.0$ & N.S vs Gr. 1 \\
Group 3 (Hyperthermia) & 10 & $28.0 \pm 3.7$ & $<0.01$ vs Gr. 1-2 \\
Group 4(free CDDP+Hyperthermia) & 10 & $29.1 \pm 6.2$ & $<0.01$ vs Gr. 1-2, N.S vs Gr. 3 \\
Group 5 (CDDP-liposome) & 10 & $32.1 \pm 3.5$ & $<0.01$ vs Gr. 1-2, $<0.05$ vs Gr. 3-4 \\
Group 6 (CIIP-liposome+Hyperthermia) & 10 & $41.6 \pm 9.5$ & $<0.01$ vs Gr. 1-4, $<0.05$ vs Gr. 5 \\
\hline
\end{tabular}

Survival of animals treated with either hyperthermia or CDDP-liposome was significantly prolonged.

Group 6, treated with both of them, had the best outcome.

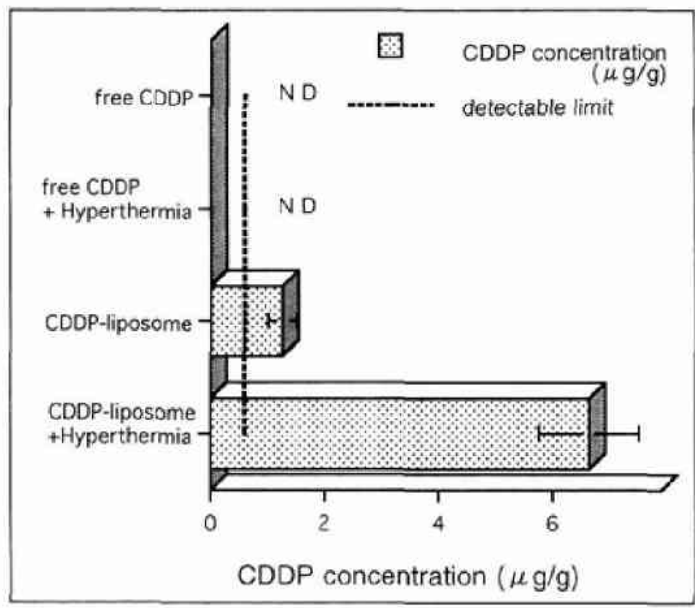

図 5 CDDP concentration in the brain tumor Brain tumor CDDP levels were significantly higher when the CDDP-liposome was used with hyperthermia, and CDDP levels were also detectable when CDDP-liposome was used without hyperthermia. Broken line shows the detectable limit of CDDP. ND is below the minimum level of detectability.

E では顕著に抗腫瘍効果が増強された。特に Group E では, Group C にくらべてさらに効果 が増強され, $4 \mu \mathrm{g} / \mathrm{g}$ 以上では有意な差がみられた ( $\mathrm{P}<0.05$ : Student's t-test).

\section{（2） CDDP-liposome の体内薬理動態}

血液中の CDDP 呩度は, CDDP-liposome を投 与した Group D, Group E の 2 群において, 20 分 後でまだきわめて高濃度に維持されており,その 後徐々に減少していった(図3). また, 加温と併用 した Group Eでは, Group D に比してその減少 速度が速まっていたが，腫㾤組織内の CDDP 濃
度は, Group E で他の治療群と比較して約 2 倍の $\mathrm{CDDP}$ の集積がみられたことから, CDDP が加温 部位に集積して消費されたためと考えられた(図 4).

（3）脳腫瘍に対する抗腫湟効果

平均生存期間（日）は, Group 1 が $19.5 \pm 2.5$, Group 2 が 20.1土3.0, Group 3 が $28.0 \pm 3.7$, Group 4 が $29.1 \pm 6.2$, Group 5 が $32.1 \pm 3.5$, Group 6 が 41.6土9.5 であった. Group 1 と 2 と の間および Group 3 と 4 との間には差がなく, free CDDP の投与は無効と考えられた。一方, Group 1，2 に比較して, 加温もしくは CDDPliposome のいずれかを用いた Group 3, 4, 5, 6 で は, 有意に生存期間が延長した $(\mathrm{P}<0.01$ ：Wilcoxon-test).さらに加温と CDDP-liposome の 両者を用いた Group 6 では最大の抗腫瘍効果が 得られた (vs Group 1-4:P $<0.01$, vs Group 5： $\mathrm{P}<0.05$ ) (表 1).

腫瘍内 CDDP 濃度も同様の結果で, 加温と CDDP-liposome の両者を用いた Group 6 では最 大の CDDP 濃度が得られた (vs Groups 2, 4: P< 0.0001 , vs Group $5: \mathrm{P}<0.001:$ Student's $\mathrm{t}-$ test). また, 加温を併用せず, CDDP-liposome の みを用いた Group 5 でも CDDP 濃度が上昇し た。一方, Groups 2, 4 では, CDDP 濃度は測定 感度 (>0.6 $\mu \mathrm{g} / \mathrm{g})$ 以下だった(図 5).

\section{考 察}

周知のように, 熱感受性リポソームは, 腫湟局 所に効果的にかつ選択的に抗癌剤を到達させ, さ らに温熱療法との相乗効果をも得られる DDS と 


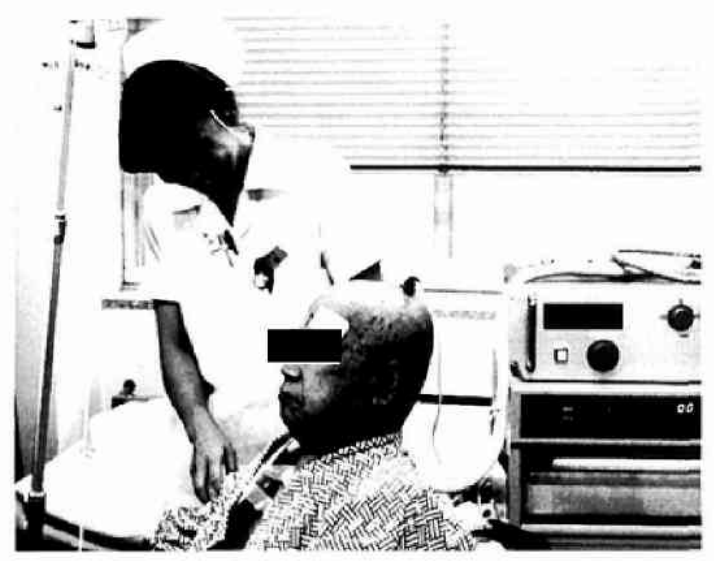

図 6 Photograph showing how hyperthermic therapy is performed clinically

して期待され，筆者らもはじめに行った実験(2)に おける皮下腫瘍のモデルに対する影著な抗腫瘍効 果と, 実験(3)の結果にみる理論的な体内薬理動態 から，この方法の有用性に確信を持った，筆者ら のほかにもこれまで多くの報告がなされてきた $か^{8 \sim 10)}$, それら報告の多くは加温の容易な皮下腫 瘍に対して行われたものであり，この魅力ある DDS も, 現在の加温技術の限界から, 深部に発育 する腫瘍には適応できないなど, その後さまざま な問題点が明らかになってきた, さらに, 脳とい う臟器の解剖学的特徴から,これまで脳腫演に本 法を応用しようとする試みは報告されていない.

筆者らの施設では，すでに 10 年以上にわたり， 悪性脳腄瘍に対する温熱療法について, 基礎的, 臨床的検討を行ってきた1). そして近年, 教室の高 橋らにより, 定位的脳手術装置を用いて直径 1.0 $\mathrm{mm}$ の加温用アンテナを脳内の任意の部位に正 確に刺入して行う, RF 組織内加温法が考案され た 2,4 6).この方法は, 局所麻酔下に少ない侵襲でア ンテナを脳内の任意の部位に刺入し, 症例を車椅 子に座らせたままで, なんら苦痛を感じさせるこ となく加温操作を行うことが可能である(図 6). さらにこの方法は, 加温用アンテナの材質の熱イ ンピーダンスを改良することにより，RF を低 powerでかつ任意に調節できるうえ，加温部位に 直径 $0.8 \mathrm{~mm}$ の多点式温度計を刺入し, 温度を real time に monitoring することにより, 事前
に計画した範囲を，計画した温度で加温できる画 期的なシステムである. 加えてこの方法は, 定位 脳手術装置によって脳内のいかなる部位にも RF antenna を正確に㨉入することができ，これまで の方法ではさらに治療が困難であった脳の深部に 存在する腫湯もよい治療の適応となる。このシス テムによって, 覀性脳腫瘍に対する熱感受性りポ ソームを用いた DDS が，実用化へ向けて具体化 してきたものと思われる。

一方,これまで脳腫璌, 特に悪性グリオーマに

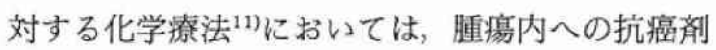
の到達を妨げる血液脳関門が存在することが大き な問題点とされ, 薬㓮の選択に当ってもっとも重 要と考えられた点は, その楽剤の血液脳関門に対 する透過性であった，そのため，悪性グリオーマ に対してはニトロソウレア系の抗癌㓮が主に用い られてきたが, それらの有効性は in vitro での強 い殺細胞効果に反して, 満足す心゙きものではない のが現状である。

今回の筆者らの脳腫湟モデルを用いた実験(4) で，通常では血液脳関門を透過しないとされる free CDDP が熱感受性リポソームに封入された ことにより, CDDP が腫瘍内に高濃度に移行し, より強力な抗腫陽効果を発揮したことは, リポ ソームと血液脳関門の関係を考えるうえで，きわ めて興味深い結果と思われた. 現在, 紐胞内に生 理活性物質を導入するなど, 細胞膜相互作用のモ デルとしても重要視されている, リポソームの持 $つ$ cell affinity に注目して, 熱感受性リポソーム とはまた別の視点から、リポソームと血液脳関門 の主役である内皮細胞の細胞膜との親和性を高 め, 血液脳関門の障壁を乗り越えようとする試み が報告されており ${ }^{12,13)}$, 今後の進展が期待されて いる、筆者らの結果も，このような内皮細胞との リポソーム独自の cell affinity の一端を示唆する ものと考えられ，現在さらに検討中である.

また筆者らは, 薬剤固有の血液脳関門透過性は, 温熱療法と併用することで一層克進することをす でに報告している ${ }^{14,15)}$. この利点と, 前記のリポ ソームと血液脳関門の親和性とが, Group 6 にお いて治療群中最大の腫㾤内 CDDP 濃度をもたら 
し,ささらに温熱による直接の殺細胞効果が加わり, これら三者の総合的な相乗効果が, この Groupに 最大の抗腫瘍効果をもたらしたものと考えられ る.

したがって本法は, (1) 抗癌剂を脳腫瘍内に高濃 度に targetできる新しい化学療法であること, (2) 温熱による直接の殺細胞効果も有するため, 化学 療法のみならず温熱療法との相乗効果が期待でき ること, (3) 加温によって血液脳関門の透過性が䒕 進すること，およぴリポソーム自身に血液脳関門 の内皮細胞との膜親和性が期待されることによっ て, 熱感受性リポソームの腫瘍への移行が高めら れ, 化学療法における血液脳関門の問題を克服で きる可能性があること, (4) また, これらの目的の 達成には十分な加温技術が必須のものとなるが, 筆者らの RF 組織内加温法はすでに臨床治療に応 用され，安全で安定した脳腫瘍の加温を達成して いることなど, 数多くの特長を備え, 悪性脳腫瘍 に対する新しい化学温熱療法として十分期待でき うると思われる。

さて, 従来から問題視されている, リポソーム の網内系による捕捉については，今回用いた熱感 受性りポソームも肝蔵, 脾臟には高濃度の集積を 示した。 しかし, 実験(4)の脳腫瘍モデルで, 治療 後網内系臓器についても病理学的検索を行った が, 光顕レベルにおいて組織学的には異常を認め なかった、これは, 脳腫瘍局所の加温が十分に達 成されたため, 再循環する熱感受性りポソーム量 が減少し,たんに静注した場合よりも網内系臟器 への集中が抑制されたとも考えられる。しかしな がら, 実際の悪性グリオーマは周囲の正常脳組織 に広く漫潤しているため, 筆者らの組織内加温法 をもってしても, 腫湯全体を完全に加温するには なお限界がある、今後臨床へ応用するためには, リポソームの網内系による捕捉量の軽減を図り, 悪性グリオーマ全体に治療範囲を拡大するために も, 脳内加温技術のさらなる改良, あるいは現在 ある加温技術の特性と限界に即した熱感受性リポ ソーム療法の新たな strategy の考案, また脂溶 性, 水溶性, いずれの抗癌剂も封入することが可 能であるといわれるリポソームの特性を生かし
て, 強力な抗腫瘍効果がありながら, 脳血液関門 を通過しないとされ，使用されてこなかった抗癌 阂の新たな選択などを考虑していく必要があろ ว.

\section{文 献}

1) Tanaka, R., Kim, C.H., Yamada, N. et al. : Radiofrequency hyperthermia for malignant brain tumors. Neurosurgery $21: 478-483,1987$.

2) Takahashi, H., Tanaka, R., Hondo, H. et al. : Preclinical experiments of RF interstitial hyperthermia with phantom and animals. Hyperthermic Oncology in Japan '90: 87-88, 1990.

3) Watanabe, M., Tanaka, R., Hondo, H., Kuroki,M. : Effect of antineoplastic agents and hyperthermia on cytotoxity toward chronically hypoxic glioma cells. Int. J. Hyperthermia 8:131-138, 1992.

4) Takahashi, H., Tanaka, R., Hondo, H. et al. : RF hyperthermia for malignant glioma-development of a needle-shaped applicator and small-sized RF generator-. Hyperthermic Oncology in Japan '91 : 133-134, 1993.

5）高橋英明, 田中隆一, 本道洋昭, 中島 拓, 渡辺正人-

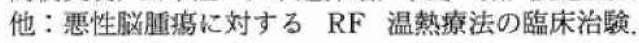
Neurosurgeons $12: 245-255,1993$.

6) 高橋英明, 田中隆一, 渡辺正人, 柿沼健一, 須田 風他：悪性脳腫癌の組織内温熱療法一RF 加温による臨 床成績一. Jpn. J. Hyperthermic Oncol. 11(1):6167, 1995.

7) Iga, K., Hamaguchi, N., Igari, Y. et al. : Enhanced antitumor activity in mice after administration of thermosensitive liposome encapsulating cisplatin with hyperthermia. J. Pharmacol. Exp. Ther. 257 : 1203-1207, 1991.

8) Nishimura, Y., Ono, K., Hiraoka, M. et al. : Treatment of murine SCC tumors with localized hyperthermia and temperature-sensitive liposomes containing cisplatin. Radiat. Res. 122:161-167, 1990.

9) Weinstein, J.N., Magin, R.L., Cysyk, R.L. et al. : Treatment of solid L1210 Murine tumors with local hyperthermia and temperature-sensitive liposomes containing methotrexate. Cancer Res. 40:1388$1395,1980$.

10) Yatvin, M.B., Mühlensiepen, H., Porchen, W. et al. : Selective delivery of liposome-associated cisDichlorodiamineplatinum (II) by heat and its influence on tumor drug uptake and growth. Cancer Res. 41: 1602-1607, 1981.

11) Takakura, K., Abe, H., Tanaka, R. et al. : Effects of ACNU and radiochemotherapy on malignant gliomas. J. Neurosurg. 64: 53-57, 1986.

12) Umezawa, F., Eto, Y.: Liposome targeting to mouse brain: Mannose as a recognition marker. Biochem. Biophys. Res. Commun. $153: 1038-1044$, 1988.

13) Yagi, K., Naoi, M., Sakai, H. et al. : Incorporation of enzyme into the brain by means of liposomes of 
novel composition. J. Appl. Biochem. 4:121-125, 1982.

14) Kakinuma, K., Tanaka, R., Takahashi, H. et al. : Targeting therapy for malignant brain tumor using thermosensitive liposome. Hyperthermic Oncology in Japan '91 : 393-394, 1993.
15) Kakinuma, K., Tanaka, R., Takahashi, H., Sekihara, Y., Watanabe, M. et al. : Drug delivery to the brain using thermosensitive liposome and local hyperthermia. Int. J. Hyperthermia $12(1): 157-$ 165, 1996. 